\title{
Impact of Thermal stress on the growth, Size-distribution and Biomass of Estuarine Populations of a Benthic Gastropod Pachymelania aurita MÜLLER
}

\author{
*11ROLAND EFE UWADIAE
}

\author{
Benthic Ecology Unit, Department of Marine Sciences, University of Lagos Akoka, Lagos, Nigeria
}

E-mail:eferoland@yahoo.com; ruwadiae@unilag.edu.ng.

\begin{abstract}
This paper reports an in-vivo account of the impact of thermal stress on the biomass and sizedistribution of estuarine populations of Pachymelania aurita in Epe Lagoon, Nigeria. Off all physicochemical variables investigated only water temperature was statistically different among study stations. A total of 7626 individuals of the organism comprising 2,371 juveniles, 3586 immature adults and 2,034of spawning adults were collected from the study area. Highest populations of juveniles and immature adults occurred in station 3 where the highest water temperature occurred while, station 1 recorded lowest populations of the two size classes. Spawning adults occurred in highest number in station 2 while their lowest population was observed in station 3.Of the total biomass of $2491 \mathrm{~g}$ recorded, juvenile population recorded a total biomass of $143.401 \mathrm{~g}$, immature adults contributed $874.424 \mathrm{~g}$ while spawning adults recorded $1473.19 \mathrm{~g}$. Highest juvenile biomass $(34.7 \mathrm{~g})$ occurred in station 5 while, the least $(17.7 \mathrm{~g})$, was recorded in station 1. Station 3 accommodated the highest biomass $(233.60 \mathrm{~g})$ of immature adults and the least biomass for this group was observed in station 1.Biomass of the spawning adults was highest $(475.08 \mathrm{~g})$ in station 2 and the lowest biomass $(162.03 \mathrm{~g})$ for this class was observed in station 3 . The elevated water temperature observed in station 3 affected the growth of the organism such that only few individuals developed to spawning adult. It is therefore important that, the regulatory agencies should carry out regular monitoring of cooling water discharge from Egbin Power Station to ensure compliance with stipulated laws. (C) JASEM

https://dx.doi.org/10.4314/jasem.v21i5.1
\end{abstract}

Keyword: Thermal stress, gastropods, growth, biomass, size distribution

The use of water for cooling in the generation of electricity has become a common practice all over the world (Langfort, 1990; Kaushal et al., 2010; Hester and Doyle, 2011). Water is used in thermal plant to keep the temperature of energy processing at the lowest possible level so as to increase electrical generating efficiency. The discharge of the cooling water back to the aquatic systems poses a lot of physiological challenge to the resident organisms, and in most cases has resulted in thermal stress. Thermal stress is a term used to describe a temperature change that is severe enough to cause unfavorable and lethal conditions in organisms, their populations, community structure or ecosystem (Heugens et al., 2001; Wałkuska and Wilczek, 2010).

Aquatic organisms have evolved to live and function most efficiently within an optimal range of water temperature (Wałkuska and Wilczek, 2010). Water temperature in aquatic system does vary by season, during the day, and along the stretch of an area. However, certain human activities and the physical condition of the aquatic ecosystem can influence water temperatures beyond natural variation to cause thermal stress (Matear, 2006; Mideska and Kallbekken, 2010).

Life - cycle of most aquatic organisms is closely and delicately related to water temperature, many of them are distributed, migrate, and spawn in response to temperature cues (Butterwick et al., 2005). When water temperature is artificially changed, the disruption of normal activities and patterns can be catastrophic. Some organisms spawn with an increase in temperature while some spawn with a decrease in temperature. According to (Wałkuska and Wilczek, 2010) Trout eggs take 165 days to hatch at $3{ }^{\circ} \mathrm{C}$, only 32 days at $12{ }^{\circ} \mathrm{C}$, and will not hatch at all above 15 ${ }^{\circ} \mathrm{C}$. Lifespan is also affected by water temperature, water fleas (Daphnia) live for 108 days at $8{ }^{\circ} \mathrm{C}$, but only 29 days at $28{ }^{\circ} \mathrm{C}$. Molluscs are known to be delicately attuned to temperature change that they spawn within a few hours after their environment reaches a critical temperature (Odiete, 1999).

The genus Pachymelania is one of the commonest gastropod molluscs in the south-western lagoon systems of Nigeria (Oyenekan, 1979). It is endemic to West Africa (Buchanan, 1954; Oyenekan, 1975), and is harvested by natives of coastal towns and villages in Nigeria as a staple source of protein. The species has received a lot of research attention due to its economic and aquaculture potentials. The shell characteristics, classification and geographical distribution of the genus have been reported by Buchanan (1954) and Longhurst (1958).The ecology of the genus in relation to changes in temperature, salinity and survival out of water under experimental conditions has been documented (Oyenekan, 1979). The genital ducts of three species ( $P$. aurita, $P$. fusca, and $P$. bryoensis) has been described (Oyenekan, 1984). The production and population dynamics of $P$. aurita in the brackish water Lagos 
Lagoon have been studied by Ajao and Fagade (1990), and Uwadiae et al. (2009) reported the ecology and natural food items of the organism.

The problem of thermal pollution in aquatic systems has not been adequately studied and is insufficiently reported in Nigeria. The use of Epe Lagoon for cooling by Egbin Thermal Power Plant involves the release of large amounts of heated water into the lagoon. In this study the impact of thermal pollution on the growth and age/size distribution of the estuarine gastropod, $P$. aurita in Epe Lagoon was investigated. The overall objective was to determine whether temperature increase in some parts of the lagoon occasioned by the discharge of heated water from the Power Station affected the growth of the organism.

\section{MATERIALS AND METHODS}

Description of study area: Epe lagoon (Fig. 1) lies between latitudes $3^{0} 50$ ' $-4^{0} 10^{\prime} \mathrm{N}$ and longitudes $5^{0} 30^{\prime}-5^{0} 40^{\prime} \mathrm{E}$. It has a surface area of about 243 $\mathrm{km}^{2}$ (Kusemiju, 1988), and is sandwiched between two other lagoons, the Lekki lagoon (freshwater) in the east and Lagos lagoon (brackish water) in the west. The lagoon which has an average depth of about $2.45 \mathrm{~m}$ is fed by the waters of adjoining rivers and creeks. The lagoon is connected to the ocean through the Lagos Harbour and tidal influence is relatively weak.

Egbin Power Station is located at Ijede Town on the shore of Epe Lagoon, about $40 \mathrm{~km}$ North East of the city of Lagos in Ikorodu Local Government Area of Lagos state, it is situated on a low land and bounded by the Lagoon to the South. It is the largest power plant in West Africa with an installed capacity of 1320 MW consisting of 6 Units of 220 MW each. The Egbin Power Plant burns fossil fuels, which primarily consists of natural gas (NG) and high pour fuel oil (HPFO) as back up, and generates steam which is converted to shaft work in the turbine and to electric power in the generator. The steam generated in the boiler enters the turbine at temperature of about $540{ }^{0} \mathrm{C}$ and pressure of $12.5 \mathrm{MPa}$ to spin the turbine blade at a very high speed of $3000 \mathrm{rev} / \mathrm{min}$ (Anozie and Ayoola, 2012). The water from the lagoon is used as cooling water. The water is passed through the condenser to enhance the condensation of water from steam. The condensed water in the condenser enters the condensate polishing plant for treatment before being sent back to the boiler for re-use. The cooling water which gains temperature from the condenser exits through a discharge channel into the lagoon. The temperature of the effluent water from the power-house is reduced in the supplementary cooling system before finally being discharged back into the lagoon (Anozie and Ayoola, 2012).

Selection of study stations for this study was carefully done in such a way that most probable areas of influence of the discharge were covered. To this end, five stations (Fig. 1; Table 1) were selected with two (Stations 1 and 2) before and two (Stations 4 and 5 ) after the discharge point (Station 3 ).

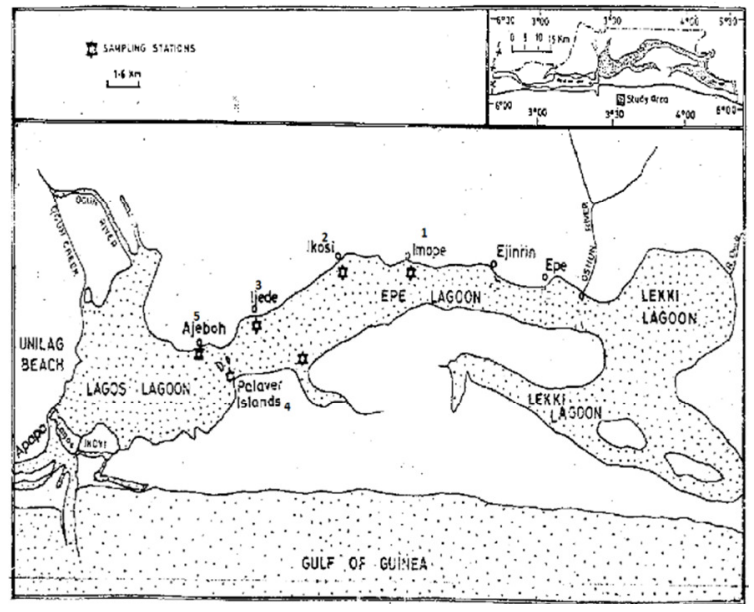

Fig1: Map of the study area showing sampling stations

Table 1: Description of sampling stations

\begin{tabular}{|c|c|c|c|}
\hline Station & Name & Coordinates & $\begin{array}{l}\text { Average } \\
\text { depth }(\mathrm{m})\end{array}$ \\
\hline 1 & Imope & Latitude $06^{0} 36.929 " \mathrm{~N}$ and Longitude $03^{\circ} 44.710^{\prime \prime} \mathrm{E}$ & 0.9 \\
\hline 2 & Ikosi & Latitude $06^{0} 36.799$ "N and Longitude $03^{\circ} 42.568^{\prime \prime} \mathrm{E}$ & 1.0 \\
\hline 3 & Ijede & Latitude $06^{0} 33.592 " \mathrm{~N}$ and Longitude $03^{0} 36.102 " \mathrm{E}$ & 0.94 \\
\hline 4 & PalavarIsland & Latitude $06^{0} 31.754 " \mathrm{~N}$ and Longitude $03^{0} 33.365^{\prime \prime} \mathrm{E}$ & 1.10 \\
\hline 5 & Ajebo & Latitude $06^{0} 31.893 " \mathrm{~N}$ and Longitude $03^{0} 31.912$ "E & 1.2 \\
\hline
\end{tabular}

pole into the water until its gets to the bottom and the level of water was read against a Measuring Tape.

Collection of samples and in-situ measurements: Water: Air and water temperatures were measured with Mercury in glass thermometer in ${ }^{0} \mathrm{C}$. Depth of study stations was obtained by inserting a wooden
Transparent and amber coloured reagent bottles of $250 \mathrm{ml}$ were used for the collection of water samples used for the analysis of Dissolved oxygen (DO) and Biochemical oxygen Demand $\left(\mathrm{BOD}_{5}\right)$, while water 
samples used for the determination of other physicochemical parameters were collected in prewashed 1 litre plastic bottles.

Sediment: Sediment samples from each sampling point were collected using van Veen grab of size $0.1 \mathrm{~m}^{2}$. The top $5 \mathrm{~cm}$ layer of each haul was collected and placed in a labelled polythene bag. The samples were preserved in the deep freezer before analysis in the laboratory.

Specimens of $P$. aurita: Three grab hauls were taken from each station, using $0.1 \mathrm{~m}^{2}$ size van Veen grab from an anchored boat with an out-board engine. The collected material was washed through a $0.5 \mathrm{~mm}$ mesh sieve in the field. The residue in the sieve was preserved in $10 \%$ formalin solution and kept in labelled plastic containers for onward transportation to the laboratory.

Laboratory analyses: Water, sediment and animal samples: Physicochemical investigations of water and sediment samples were carried out using the procedures outlined in Standard Methods for the Examination of Water and Wastewater (APHA, 1985). Preserved $P$. aurita samples were washed with tap water to remove the preservative and remaining sediment in order to facilitate easy sorting. The animals were sorted on a white tray and the identity of individual specimen confirmed using suitable texts Edmunds (1978) and Yankson and Kendall (2001). The number of species and individuals for each station were counted and recorded.

Population Studies: Samples of P. aurita from study stations for each sampling month were divided into three age-groups; $\mathrm{O}=$ Juveniles $(0-10 \mathrm{~mm}) ; \mathrm{I}=$ Immature Adults $(10-17 \mathrm{~mm}) ; \mathrm{SA}=$ Spawning Adults $(>17 \mathrm{~mm})$ to represent the composition of the population at a given month. All individuals belonging to each age-group were counted and recorded.

Biomass Studies: The biomass of each age-group was determined by wet method. This involves direct weighing of all the sorted animals of each group (Holme and Mclntyre, 1971).The organisms were allowed to dry for one minute after puncturing the shells with a fine needle and the mantle cavity water sucked up with filter paper. The organisms were then weighed using a weighing balance and values approximated to the nearest weight in gramme $(\mathrm{g})$.

Statistical analysis: One-Way analysis of variance (ANOVA) was used to compare the variations in physicochemical parameters and fauna variables at the study sites. When significant variations are detected, a post hoc test using Duncan Multiple Range Test for physicochemical parameters (DMRT) and Tukey's Honestly Significantly Different (HSD) test for fauna variables were performed to determine the locations of significant differences. The relationships between biotic and environmental parameters were determined using Spearman rank correlations (Sokal and Rohlf, 1981). All statistical analyses were performed with SPSS 10 and Excel 2013 for Windows.

\section{RESULTS AND DISCUSSION}

Physicochemical Parameters: The summary of values recorded for physicochemical parameters investigated is presented in Table 2. The values of air and water temperatures were consistent during the study period, except for the relatively higher water temperature observed in station 3 . The highest value of air temperature $\left(36{ }^{0} \mathrm{C}\right)$ was recorded in station 3 and 5 while the least value $\left(24{ }^{0} \mathrm{C}\right)$ was observed in station 2. Highest water temperature $\left(43{ }^{\circ} \mathrm{C}\right)$ was recorded in station 3 , while the least $\left(23{ }^{\circ} \mathrm{C}\right)$ occurred in station 4. Values recorded for $\mathrm{pH}$ fluctuated between 6.11 at station 3 and 8.6 in station 4. Station 4 had the highest values $(15 \mathrm{mg} / \mathrm{L})$ for $\mathrm{DO}$, while the least value $(3.5 \mathrm{mg} / \mathrm{L})$ was recorded at station 5 . The range of BOD for the period of studywas4 - 114.4 $\mathrm{mg} / \mathrm{L}$ while COD varied between $97.4 \mathrm{mg} / \mathrm{L}$ obtained in station 5 and $554 \mathrm{mg} / \mathrm{L}$ in station 2 .The highest value $(6.5 \mathrm{mg} / \mathrm{L})$ of phosphate was recorded in station 5 , while the lowest $(0.12 \mathrm{mg} / \mathrm{L})$ was recorded in station 2 . The lowest value of nitrate $(0.15 \mathrm{mg} / \mathrm{L})$ was observed in station 4 while the highest value $(12.2 \mathrm{mg} / \mathrm{L})$ was in station 1 .

The percentage of sand in sediment was consistently higher than that of mud at the study stations. Highest value $(93.6 \%)$ of sand was recorded in station 2 and the lowest $(65.4 \%)$ occurred in station 1. Percentage mud varied between $6.5 \%$ obtained station 2 and $29 \%$ in station 4. Total organic content in sediment was highest $(7.5 \%)$ in stations 1 and 3 and the least value $(1.01 \%)$ recorded was observed in four $(1,3,4$, and 5) of the stations studied.

Values of physicochemical parameters except temperature are within the range reported by previous workers for Epe Lagoon (Uwadiae et al., 2009) and other water bodies in the same vicinity (Ajao and Fagade, 1990).

Population dynamics of the different Age groups: A total 7,626 individuals of $P$. aurita comprising 2,371 individuals of juveniles, 3,586 immature adults and 2,034of spawning adults were collected from the study area. The populations of the various age groups of $P$. aurita collected over the one-year period of 
study demonstrated high level of variability (Table 3). Spatial and temporal variations in the number of individuals of the different age groups are shown in Figures $2-4$, while Figure 5 depicts percentage

Table 2: Summary of physicochemical characteristics of study stations

\begin{tabular}{|c|c|c|c|c|c|c|c|c|c|c|c|c|c|c|c|}
\hline \multirow[b]{2}{*}{ Parameter/Unit } & \multicolumn{14}{|c|}{ Sampling stations } & \\
\hline & 1 & & & 2 & & & 3 & & & 4 & & & 5 & & \\
\hline Water & 丞 & 吉 & 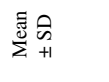 & 泾 & 具 & 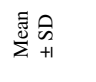 & $\stackrel{\text { J }}{\Sigma}$ & $\stackrel{\Xi}{\Sigma}$ & 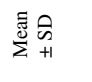 & $\stackrel{\text { m }}{\Sigma}$ & 具 & 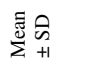 & $\stackrel{\frac{\pi}{\pi}}{\Sigma}$ & $\stackrel{\Xi}{\Sigma}$ & $\sum_{\Sigma}^{\mathbb{E}}$ \\
\hline $\begin{array}{l}\text { Air temperature } \\
\left({ }^{\circ} \mathrm{C}\right)\end{array}$ & 35 & 29 & $\begin{array}{l}32.58 \pm \\
1.92\end{array}$ & 34 & 24 & $31 \pm 2.64$ & 36 & 25 & $\begin{array}{l}32.5 \pm \\
2.62\end{array}$ & 35 & 28 & $31.97 \pm 2.5$ & 36 & 29 & $\begin{array}{l}32.83 \pm \\
2.15\end{array}$ \\
\hline $\begin{array}{l}\text { Water temperature } \\
\left({ }^{\circ} \mathrm{C}\right)\end{array}$ & 35 & 25 & $32 \pm 3.34$ & 36 & 24 & $33 \pm 4$ & 43 & 29 & $38 \pm 2.76$ & 36 & 23 & $32 \pm 3$ & 35 & 28 & $33 \pm 2.47$ \\
\hline$(\mathbf{p H}$ & 8.5 & 6.12 & $7.29 \pm 0.59$ & 8.1 & 6.7 & $\begin{array}{l}7.42 \pm \\
0.39\end{array}$ & 7.9 & 6.11 & $\begin{array}{l}7.20 \pm \\
0.38\end{array}$ & 8.6 & 6.2 & $7.18 \pm 0.5$ & 8.4 & 6.2 & $\begin{array}{l}7.10 \pm \\
0.44\end{array}$ \\
\hline DO (mg/L) & 13 & 3.2 & $5.5 \pm 2.32$ & 14 & 2.4 & $5.8 \pm 3.04$ & 10.5 & 4 & $\begin{array}{l}5.7 \pm \\
1.75\end{array}$ & 15 & 4.2 & $6.7 \pm 2.6$ & 12.1 & 3.5 & $5.9 \pm 2.25$ \\
\hline BOD $_{5}(\mathrm{mg} / \mathrm{L})$ & 42.2 & 4.4 & $17.8 \pm 9.17$ & 27 & 5.6 & $\begin{array}{l}13.4 \pm \\
16.4\end{array}$ & 72.1 & 5.1 & $\begin{array}{l}16.5 \pm \\
13.30\end{array}$ & 114.4 & 4 & $17.6 \pm 21.9$ & 41.6 & 7 & $\begin{array}{l}16.1 \pm \\
8.05\end{array}$ \\
\hline $\operatorname{COD}(\mathrm{mg} / \mathrm{L})$ & 405 & 111.6 & $\begin{array}{l}238.1 \pm \\
202.6\end{array}$ & 554 & 112 & $\begin{array}{l}304.1 \pm \\
120\end{array}$ & 350 & 120 & $\begin{array}{l}217.5 \pm \\
58.2\end{array}$ & 341 & 146 & $\begin{array}{l}208.9 \pm \\
81.3\end{array}$ & 385 & 97.4 & $\begin{array}{l}217.2 \pm \\
95.4\end{array}$ \\
\hline $\mathrm{PO}_{4}-\mathrm{P}(\mathrm{mg} / \mathrm{L})$ & 4.88 & 0.32 & $2.13 \pm 1.29$ & 5.6 & 0.12 & $\begin{array}{l}2.02 \pm \\
1.69\end{array}$ & 4.75 & 0.28 & $\begin{array}{l}1.59 \pm \\
1.61\end{array}$ & 6.17 & 0.4 & $1.86 \pm 1.7$ & 6.5 & 0.23 & $\begin{array}{l}1.69 \pm \\
1.76\end{array}$ \\
\hline $\mathrm{NO}_{3}-\mathrm{N}(\mathrm{mg} / \mathrm{L})$ & 12.2 & 0.21 & $2.56 \pm 2.51$ & 4.25 & 0.85 & $\begin{array}{l}1.90 \pm \\
0.87\end{array}$ & 5.15 & 0.51 & $\begin{array}{l}2.14 \pm \\
1.36\end{array}$ & 6.01 & 0.15 & $2.09 \pm 1.8$ & 6.8 & 0.4 & $\begin{array}{l}2.66 \pm \\
1.80\end{array}$ \\
\hline $\begin{array}{l}\text { Sediment } \\
\text { Sand }(\%)\end{array}$ & 85.4 & 65.4 & & 93.6 & 71.4 & & 92.2 & 73.6 & & 89 & 65.8 & & 92.4 & 73.5 & \\
\hline Mud (\%) & 27.6 & 14.6 & & 28.6 & 6.5 & & 26 & 7.8 & & 29 & 11 & & 26.5 & 7.6 & \\
\hline $\operatorname{TOC}(\%)$ & 7.5 & 1.01 & & 7.3 & 1.02 & & 7.5 & 1.01 & & 6 & 1.01 & & 6.3 & 1.01 & \\
\hline
\end{tabular}

Table 3: Summary of the number of individuals and wet weight of P.aurita recorded in the study station

\begin{tabular}{|c|c|c|c|c|c|c|c|c|c|c|c|c|c|c|c|}
\hline \multirow[b]{2}{*}{ Number of individuals } & \multicolumn{15}{|c|}{ Sampling stations } \\
\hline & 1 & & & 2 & & & 3 & & & 4 & & & 5 & & \\
\hline & Mea & $\mathrm{Ma}$ & $\mathrm{Mi}$ & Mea & $\mathrm{Ma}$ & $\mathrm{Mi}$ & Mea & $\operatorname{Max}$ & M & Mea & $\operatorname{Max}$ & $\mathrm{Mi}$ & Mea & $\mathrm{Ma}$ & $\mathrm{Mi}$ \\
\hline & $\mathrm{n}$ & $\mathrm{X}$ & $\mathrm{n}$ & $\mathrm{n}$ & $\mathrm{x}$ & $\mathrm{n}$ & $\mathrm{n}$ & & in & $\mathrm{n}$ & & $\mathrm{n}$ & $\mathrm{n}$ & $\mathrm{x}$ & $\mathrm{n}$ \\
\hline $0-10 \mathrm{~mm}$ & 9.6 & 23 & 1 & 21.5 & 72 & 0 & 30.1 & 58 & 0 & 21.7 & 46 & 0 & 23 & 62 & 0 \\
\hline $11-17 \mathrm{~mm}$ & 24.5 & 67 & 8 & 27.2 & 61 & 0 & 40.6 & 81 & 23 & $\begin{array}{l}33.1 \\
4\end{array}$ & 57 & 0 & 32 & 69 & 0 \\
\hline$>17 \mathrm{~mm}$ & 18.7 & 50 & 2 & 26.2 & 79 & 0 & 17.7 & 39 & 0 & 20.9 & 61 & 0 & $\begin{array}{l}17.0 \\
5\end{array}$ & 42 & 0 \\
\hline Wet Weight (g) & & & & & & & & & & & & & & & \\
\hline $0-10 \mathrm{~mm}$ & 0.7 & 1.9 & $\begin{array}{l}0.0 \\
5\end{array}$ & 1.43 & $\begin{array}{l}4.1 \\
5\end{array}$ & 0 & 1.24 & 3.52 & 0 & 1.46 & 3.01 & 0 & 1.57 & $\begin{array}{l}5.0 \\
9\end{array}$ & 0 \\
\hline $11-17 \mathrm{~mm}$ & 5.37 & $\begin{array}{l}10 . \\
5\end{array}$ & $\begin{array}{l}1.9 \\
6\end{array}$ & 7.15 & $\begin{array}{l}15 . \\
2\end{array}$ & $\begin{array}{l}0.1 \\
5\end{array}$ & 9.7 & 20.8 & $\begin{array}{l}2 . \\
6\end{array}$ & 8.07 & $\begin{array}{l}16.8 \\
5\end{array}$ & 0 & 8.5 & $\begin{array}{l}20 . \\
7\end{array}$ & 0 \\
\hline$>17 \mathrm{~mm}$ & $\begin{array}{l}13.7 \\
6 \\
\end{array}$ & $\begin{array}{l}37 . \\
5\end{array}$ & $\begin{array}{l}1.1 \\
4\end{array}$ & $\begin{array}{l}20.6 \\
6 \\
\end{array}$ & $\begin{array}{l}67 . \\
5\end{array}$ & 0.5 & 6.75 & $\begin{array}{l}30.2 \\
3\end{array}$ & 0 & $\begin{array}{l}13.3 \\
1\end{array}$ & $\begin{array}{l}56.4 \\
2 \\
\end{array}$ & 0 & 7.75 & $\begin{array}{l}25 . \\
7\end{array}$ & 0 \\
\hline
\end{tabular}

A total of 2,371 individuals of juveniles were recorded and spatial analysis in the population distribution shows that, the highest number (686) of juveniles, approximately $29 \%$ occurred in station 3 while, the least number (230), approximately $10 \%$ was recorded in station 1 . Stations 2,4 and 5 recorded 515, 434 and 506 individuals respectively. The number of individuals of juveniles observed in the study stations per sampling month varied between 0 and 72. No juvenile was recorded in some of the stations during the sampling months, the highest number (72) of individuals occurred in station 2 . Station 3 also recorded the highest mean value of juveniles per sampling month (30) while the least mean value (10) was observed in station 1 . The population of juveniles appears to be generally lower in station 1 and higher in station 3 . representation of the various age groups at the study stations. 
evaluation of differences in population shows that, the highest number (628) of spawning adults, approximately $31 \%$ occurred in station 2 while, the least number (212), approximately $10 \%$ was recorded in station 3. Other stations (1, 4 and 5) recorded 448, 439 and 307 individuals respectively. The number of individuals of spawning adults observed in the study stations per sampling month varied between 0 and 79 . The highest number (79) of individuals occurred in station 2, station 3 recorded the highest mean value per month (26) of spawning adults while the least value per month (17.05) was observed in station 5 . The population of spawning adults was generally lower in station 3 and higher in station 2.

This study demonstrates, for the first time, that the elevated levels of water temperature associated with the discharge of hot water in Egbin Power Plant negatively impacted on the growth, size distribution and biomass of $P$. aurita in Epe Lagoon. Comparing the result of this in-vivo investigation with the output of any previous study in Nigeria is difficult since to best of my knowledge no such study has been reported in the Nigerian waters. However, the result obtained here compares favourably with the reports of Hart and Fuller (1979) and those of Talmage and Gobler (2011) on effects of elevated temperature on the growth and survival of larvae and juveniles of three species of Northwest Atlantic bivalves. Hence the discussion provided here centres on the similarities and observations common to the results reported.

The population distribution of the different size classes of the organism shows that, the elevated water temperature in station 3 was the major factor that controlled the observed pattern in that station, thereby implicating temperature as a major environmental factor that affected the growth of the benthic gastropod. Water temperature recorded in other study stations $(1,2,4$, and 5) ranged between 23 and $36^{\circ} \mathrm{C}$, while that of station 3 varied between 29 and $43{ }^{\circ} \mathrm{C}$. The generally higher temperature in station 3 is attributed to the discharge of hot water from Egbin Power Plant. Although, temperature in water bodies can be changed naturally from solar energy absorption, since water bodies absorb very little solar energy, it is assumed that its influence causes insignificant daily water temperature change. However, human activities such as the removal of riparian zone plants and release of hot water into aquatic systems cause more dramatic effects (Gray and Edington, 1969).

Critical evaluation of the major highlights of the result presented in this study shows that, the population of juveniles appear to be generally lower in station 1 and higher in station 3, those of immature adults like that of the juveniles were generally lower in station 1 and higher in station 3 while, the population of spawning adults was generally lower in station 3 and higher in station 2. The highest biomass $(20.8 \mathrm{~g})$ of immature adults occurred in station 3, which also recorded the highest mean value $(9.7 \mathrm{~g})$ of this class per sampling month. Station 3 seems to be a very hostile environment for the growth and development of $P$. aurita to adulthood or full size. The few specimens of spawning adults collected from the station may have migrated into that environment from areas with more favourable temperature regimes. This is because; reports have shown that, values of water temperature obtained in station 3 do not favour growth and development of most molluscs (Hart and Fuller, 1979; Langfort 1990; Luksiene et al., 2000)

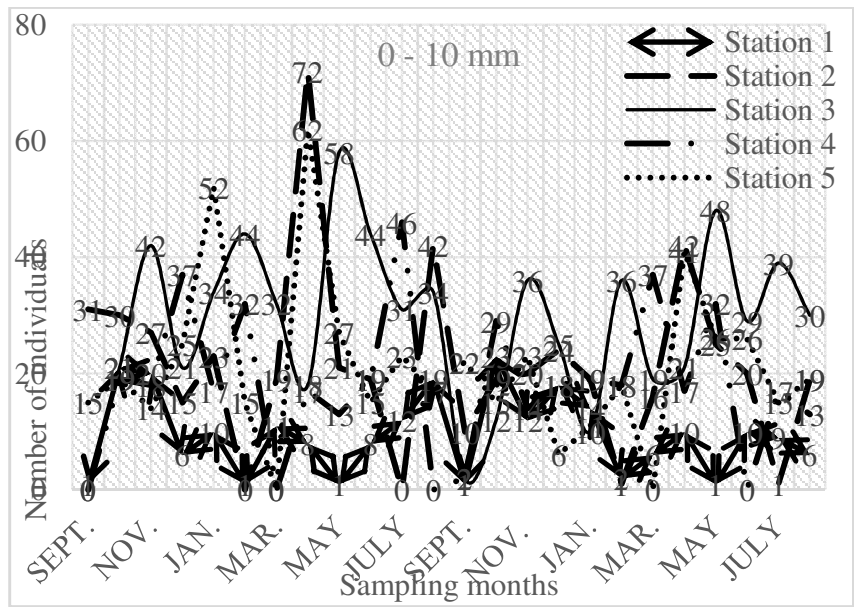

Fig. 2: Variation in the monthly number of individuals of juveniles at the study stations

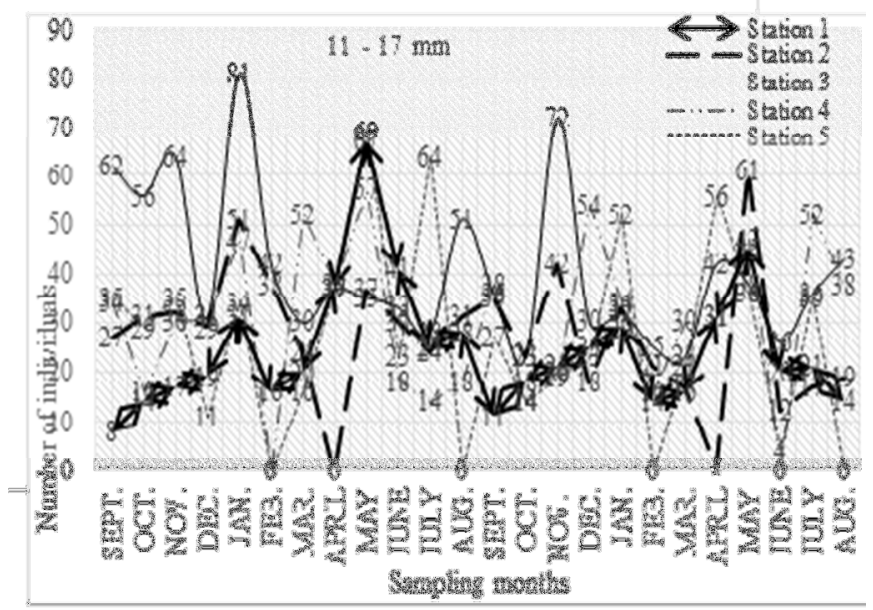

Fig. 3: Variation in the monthly number of individuals of immature adults at the study stations 


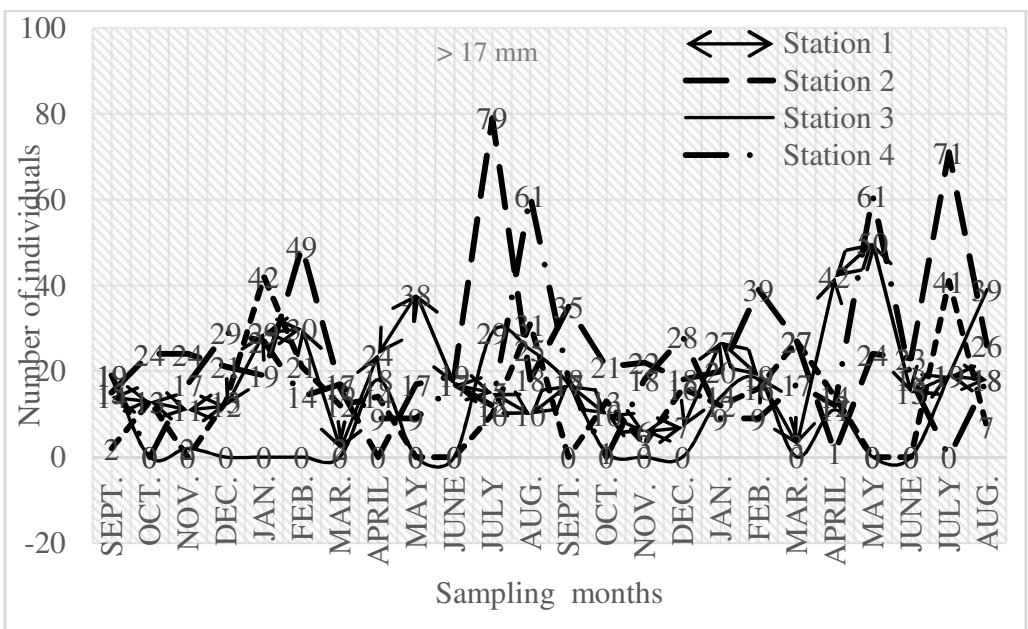

Fig.4. Variation in the monthly number of individuals of spawning adults at the study stations
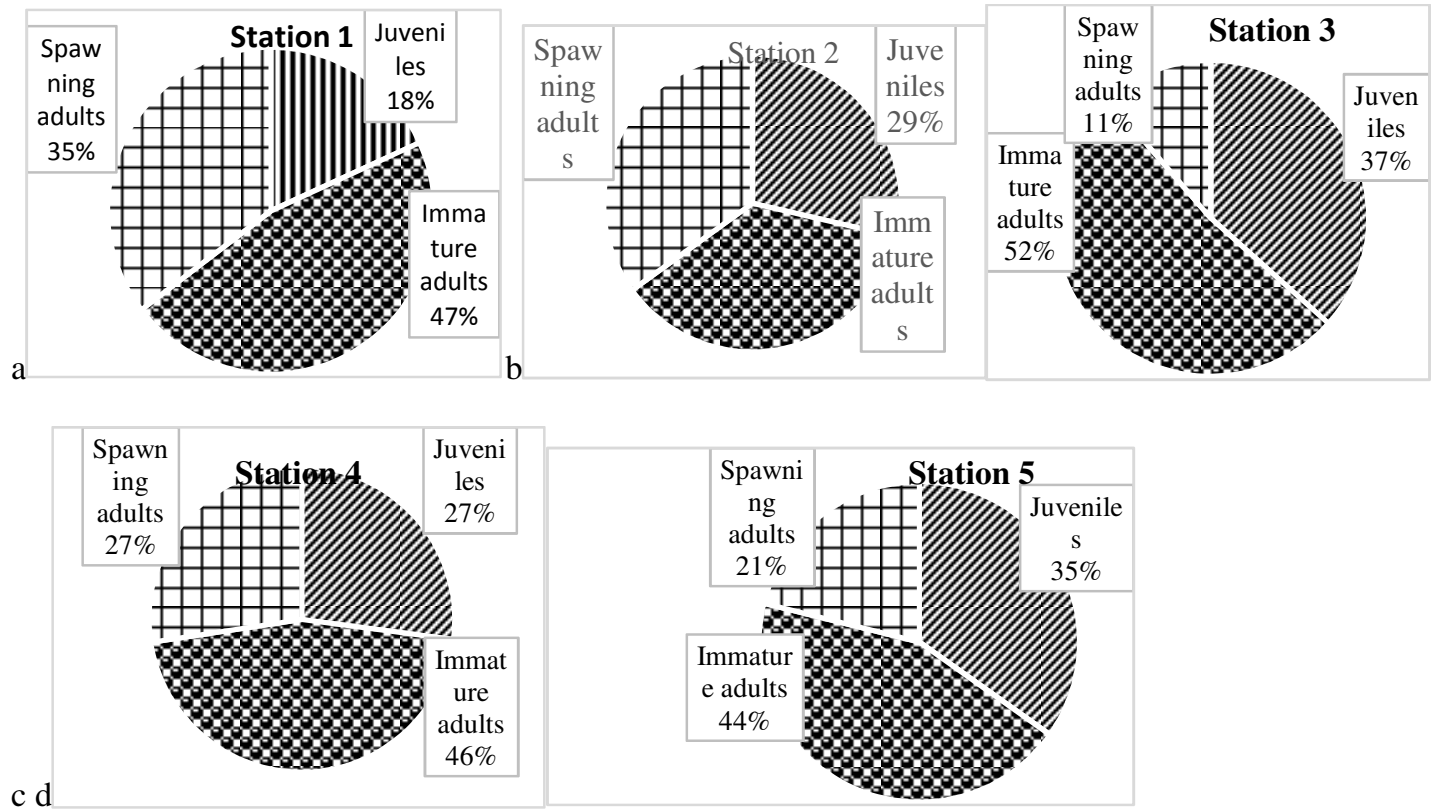

e

Fig.5: A - E. Percentage representation of the different age groups in the study stations

and $5.09 \mathrm{~g}$. The highest number $(5.09 \mathrm{~g})$ of

Variation in biomass of the different age groups: Spatial and temporal fluctuations in biomass of the different age groups are shown in Table 3 and Figs. 6 -8 . The total biomass of $P$. aurita recorded during the period of study was $2491 \mathrm{~g}$. The juvenile population recorded a total biomass of $143.401 \mathrm{~g}$ distributed in the five study stations. The highest biomass (34.7 g) which constitute approximately $24 \%$ of the total juvenile biomass occurred in station 5 while, the least $(17.7 \mathrm{~g})$, approximately $0.12 \%$ was recorded in station 1 . Stations 2, 3 and 4 recorded $34.4 \mathrm{~g}, 28.72 \mathrm{~g}$ and $34.7 \mathrm{~g}$ of juvenile biomass respectively. Biomass of juveniles observed in the study stations per sampling month varied between 0 individuals occurred in station 5 .

Station 5 also recorded the highest mean value per month $(1.5 \mathrm{~g})$ of juvenile biomass while the least mean value $(0.7 \mathrm{~g})$ was observed in station 1 .

Immature adults had a total biomass of $874.424 \mathrm{~g}$. the highest biomass (233.60 g) observed for immature adults approximately $26 \%$ occurred in station 3 while, the least (128.89 g) approximately $15 \%$ was recorded in station 1 . Stations 2,4 and 5 recorded $164.49 \mathrm{~g}, 177.66 \mathrm{~g}$ and $169.49 \mathrm{~g}$ of immature adult biomass respectively. Biomass observed in the study stations per sampling month varied between 0 and 
$20.8 \mathrm{~g}$. The highest biomass (20.8 g) immature adults occurred in station 3 , which also recorded the highest mean value $(9.7 \mathrm{~g})$ per sampling month.

For the spawning adults, a total biomass of $1473.19 \mathrm{~g}$ was recorded. The highest biomass (475.08 g) observed approximately $32 \%$ occurred in station 2 while, the least (162.03 g) approximately $11 \%$ was recorded in station 3. Stations 1,4 and 5 recorded $330.42 \mathrm{~g}, \quad 319.51 \mathrm{~g}$ and $186.15 \mathrm{~g}$ biomass respectively. Biomass observed in the study stations per sampling month varied between 0 and $67.5 \mathrm{~g}$. Station 2recorded the highest total biomass per station and highest mean value (20.7 g) per sampling month

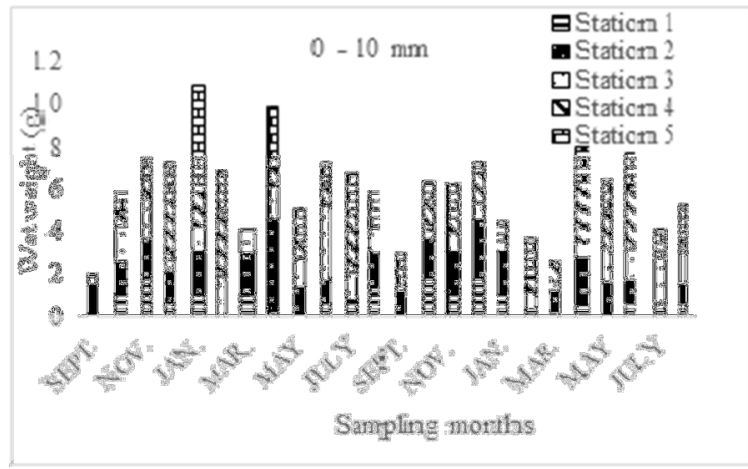

Fig. 6: Variation in the monthly biomass of juveniles at the study stations

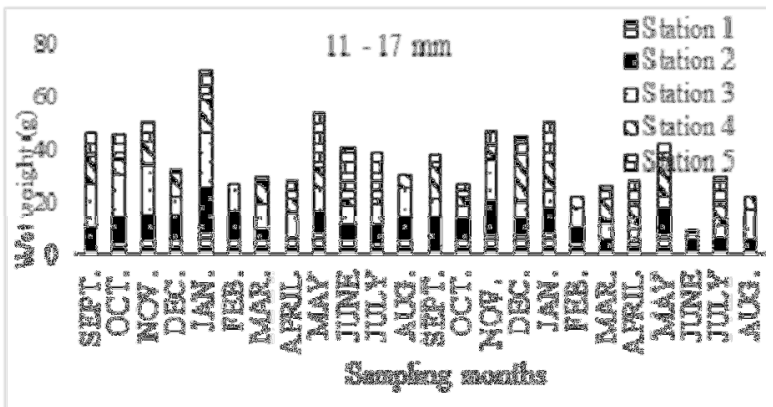

Fig.7. Variation in the monthly biomass of immature adults at the study stations

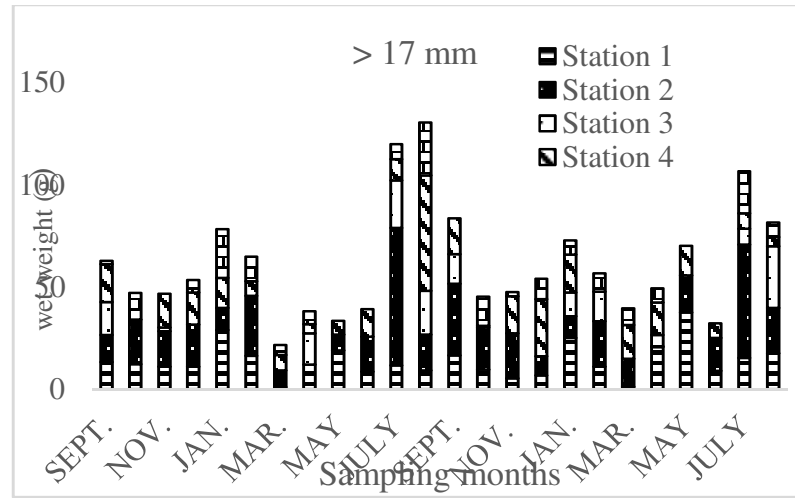

Fig. 8: Variation in the monthly biomass of spawning adults at the study stations

In the more tropical regions many animals are living near their upper thermal limits, and few degrees increase in temperature would be fatal (Vannote and Sweeney, 1980). Of equal importance, even when death does not occur, is the interruption of the normal maturation and spawning cycles (Luksiene et al., 2000). In this present study, the later may be plausible in explaining the observed pattern. According to Hart and Fuller (1979), molluscs are geared towards a cycle of growth and build-up of reserves to be converted to gamete and subsequent spawning. A continuous production of gametes occurs, which would result in little or no growth because, all energy is used for producing the gametes. The authors observed that, shell growth of hard clam (native to New York) when transplanted to Florida waters, was reported to have ceased when the temperature reached about $27^{\circ} \mathrm{C}$. Warm water might cause spawning when the proper kind of phytoplankton food is not present in sufficient abundance, or the larvae might be carried by the currents to colder water, which would be detrimental to them (Wałkuska and Wilczek, 2010).

Talmage and Gobler (2011) observed that, temperature significantly affected growth and lipid synthesis in both juvenile and larval stages of bivalves. For example, in Mercenaria mercenaria larvae, temperature had a significant, effect on metamorphosis. The percentage of individuals that had metamorphosed and survived, as well as individual growth rates were all highest for individuals grown at $24{ }^{0} \mathrm{C}$ and were lowest for individuals grown at $28{ }^{0} \mathrm{C}$. Regarding size, $M$. mercenaria larvae at $24{ }^{0} \mathrm{C}$ had mean diameters of $553 \pm 38 \mu \mathrm{m}$ while increasing temperatures progressively depressed sizes with individuals grown at $28{ }^{0} \mathrm{C}$ having mean diameters of $325 \pm 22 \mu \mathrm{m}$. Lipid indices for $M$. mercenaria were always higher at 24 ${ }^{0} \mathrm{C}$ compared to larvae grown at $28{ }^{0} \mathrm{C}$.

In this study, total biomass of the species was highest $(666.285 \mathrm{~g})$ in station 2 . This may be attributed to the favourable environmental characteristics prevalent in this site, these include a relatively high sand content with proportionate admixture of silt-clay and organic matter which has been reported to favour the growth and development of the organism (Uwadiae et al., 2009). The lowest total biomass value (390.96 g) was recorded at station 3 . The results of biomass recorded in this study indicates that total biomass value in station 3 is much lower than those (range: 47.513 $7082.7646 \mathrm{mg}$ ) reported by Ajao and Fagade (1990) in the Lagos Lagoon for this same species, therefore 
supportive of the fact that temperature negatively impacted on the organism.

The juvenile stage represent a critical life stage for mollusc populations, reductions in the growth and survival of juveniles have the potential to translate into substantial declines in adult populations(Hester and Doyle, 2011;Bear et al., 2007). This may account for the low number of spawning adult populations recorded in station 3 . The high temperature observed in the station created a major challenge for the development of the organism into full adults. Temperature has a primary influence on the spawning, growth, and development of gastropods. Gastropods are known to spawn when water temperatures reach $23-25{ }^{0} \mathrm{C}$ (Hellawell, 1989). Resultant larvae grow optimally at temperatures within $24-25^{\circ} \mathrm{C}$, but may experience slowed growth and even enhanced mortality at higher temperatures (Beitinger et al., 1999).This is may have been responsible for the high number of juveniles and immature adults in station 3. As observed by Hart and Fuller (1979), continuous production of gametes occurs under high temperature conditions, and this results in little or no growth, but enhanced production of gametes because, all energy generated by the animal under this condition is used for gametogenesis. The authors also posit that, in molluscs cessation of shell growth under high temperature conditions has been reported.

Aquatic organisms are highly dependent on specific thermal conditions in their environments, water temperatures above or below optimal thermal regimes cancause stress or even death (Beitinger et al., 1999; Killeen et al., 1998;Caissie,2006).Water temperature has a significant influence on activity and life cycles in poikilothermic aquatic organisms. Temperature affects the speed of egg development and growth of offspring that, consequently, controls the number of generations in a year, period of growth, and effectiveness of an organisms' colony. Seasonal temperature changes are often a signal to begin development and allow for the synchronization of life cycle with seasonal changes in the environment (Beitinger et al., 1999).

Therefore, it is important that water bodies receiving thermal discharges from industrial sources be subjected to frequent monitoring in order to detect changes that may result in total breakdown of ecological stability. For Epe Lagoon, I call on the Nigerian Regulatory Agencies to carry out regular monitoring and evaluation of the impact of thermal discharge from Egbin Power station on the lagoon in order to forestall further ecological damage.

\section{REFERENCES}

Ajao, EA; Fagade, SO (1990). Production and population dynamics of Pachymelania aurita MÜLLER. Arch. Hydrobiologia 120: 97- 109.

Anozie, AN; Ayoola, PO (2012)..The influence of throughput on thermodynamic efficiencies of a Thermal Power Plant. International Journal of Energy Engineering 2(5): 266-272

Bear, EA; McMahon, TE; Zale, AV (2007). Comparative thermal requirements of west slope cutthroat trout and rainbow trout: implications for species interactions and development of thermal protection standards. Trans. Am. Fisheries Soc. 136 1113-21

Beitinger, TL; Bennett, WA; McCauley, RW (1999). Temperature tolerances of North American freshwater fishes exposed to dynamic changes in temperature. Environ. Biol. Fishes 58 237-75

Buchanan, JB (1954). Marine molluscs of Gold Coast, West Africa.J. West Africa Sci. Ass., 7: 30 -45 .

Butterwick, C; Heaney, SI; Talling, JF (2005). Diversity in the influence of temperature on the growth rates of freshwater algae and its ecological relevance. Freshwat. Biol. 50: 291311.

Caissie, D (2006). The thermal regime of rivers: a review. Freshwater Biology 51:1389-406

De Vries, P; Tamis, JE; Murk, AJ; Smit, MGD (2008). Development and application of a species sensitivity distribution for temperatureinduced mortality in the aquatic environment. Environ. Toxicol. Chem. 27: 2591-8

Edinger, JE; Duttweiler, DW; Geyer, JC (1968).The response of water temperatures to meteorological conditions. Water Resources Res. 4: 1137-43

Edmunds, J (1978). Sea shells and molluscs found on West African Coasts and Estuaries. Ghana University Press, Accra. 146pp.

Gray, JRA; Edington, JM (1969). Effect of woodland clearance on stream temperature. J. Fish. Res. Board Can. 26: 399,

Hart, CW; Fuller, SHL (1979). Pollution Ecology of Estuarine Invertebrates. Academic Press Inc. London, Ltd. 406pp. 
Hellawell, M (1989). The biological indicators of freshwater pollution and environmental management. Applied Science Publishers, London. 312pp

Hester, ET; Doyle, MW (2011). Human impacts to river temperature and their effects on biological processes: a quantitative synthesis. J. Am. Water Resources Assoc.47:571-87

Holme, NA; Mclntyre, AD (1971). Methods for the study of marine benthos.IBP Handbook No. 16. International Biological Programme, London, Oxford and Edinburgh. Blackwell Scientific Publications. 334pp.

Heugens, EHW;Hendriks, AJ; Dekker, T; van Straalen, NM;Admiraal, W (2001). A review of the effects of multiple stressorson aquatic organisms and analysis of uncertainty factors foruse in risk assessment. Crit. Rev. Toxicol. 31:247-84

Kaushal, SS; Likens, GE; Jaworski, N; Pace, ML; Sides, AM; Seekell, D; Belt, KT; Secor, DH; Wingate, RL (2010). Rising stream and river temperatures in the United States. Front. Ecol. Environ. 8: 461-6

Killeen, J; Mclay, HA; Johnston, IA (1999). Development in Salmotrutta at different temperatures with a quantitative scoring method for intraspecific comparisons. J. Fish Biol. $55: 382$.

Langford, TE (2001). Thermal discharges and pollution. Encyclopedia of Oceanic Sciences (New York: Academic).

Langfort, TE (1990). Ecological Effects of Thermal Discharges. Elsevier Applied Science, pp. 1-6.

Longhurst, AR (1958). An Ecological Survey of the West African Benthos. London Fisheries Publ. 11: 104.

Luksiene, D; Sandstrom, O; Lounasheimo, L; Anderson, J (2000). The effects of thermal effluents exposure on the gametogenesis of female fish.Journal of Fish Biology56:37.

Matear, R (2006). Global warming projection of the change in dissolved oxygen concentrations in low oxygen regions of the oceans. Suplemento Gayana 15: 70:46.
Mel'nichenko, NA; Koltunow, M; Vyskrebentsev, AS (2008).The temperature dependence of the solubility of oxygen in sea water according to the pulsed NMR data.Russian Journal of Physical Chemistry A82:746.

Odiete, WO (1999). Environmental Physiology of Animals and Pollution. Diversified Resources Ltd., Lagos. 261pp.

Oyenekan, JA (1979). The ecology of the genus Pachymelania in the Lagos lagoon. Arch. Hydrobiol.86(4): 115-522.

Oyenekan, JA (1984). The genital ducts of Pachymelania (Gastropoda: Cerithiacea) in Nigeria. Biologia Africana1:31-38.

Uwadiae, RE; Edokpayi, CA; Egonmwan, RI (2009). The ecology and natural food components of Pachymelania aurita MÜLLER (Gastropoda: Melaniidae) in a Coastal lagoon. Report and Opinion 1(5):41-48.

Sokal, RR; Rohlf, FJ (1981). Biometry: the principles and practice of statistics in biological research, 2nd ed. Freeman: San Francisco. 859pp.

Vannote, RL; Sweeney, BW (1980). Geographical analysis of thermal equilibra: a conceptual model for evaluating the effect of natural and modified thermal regimes on aquatic insect communities. Am. Nat., 115:667.

Wałkuska1, G; Wilczek, A (2010). Influence of discharged heated water on aquatic ecosystem Fauna. Polish Journal of Environmental Studies 19(3):547-552

Yankson, K; Kendall, M (2001). A Student's guide to the seashore of West Africa. Marine Biodiversity Capacity Building in the West African Subregion. Darwin Initiative Report 1, Ref. 162/7/451. 305pp 